А.А. Бзезян

DOI: 10.7256/2070-8955.2014.1.9704

\title{
ВЛИЯНИЕ ГЕНДЕРА ЭТНОКУЛЬТУРНОГО ТИПА ВНЕШНЕГО ОБЛИКА НА СТЕПЕНЬ ПОЗИТИВНОСТИ ОЦЕНКИ
}

\begin{abstract}
Аннотация. Статья направлена на изучение влияния гендерной принадлежности этнокультурного типа внешнего облика на степень позитивности оценки. Предполагается, что степень позитивности различных видов оценок типа внешнего облика может быть обусловлена его этнокультурной и гендерной принадлежностью. Приводятся результаты сравнительного анализа позитивности/негативности эстетических оценок, привлекательности для противоположного пола и степени соответствия гендеру мужского и женского внешнего облика различных этнокультурных типов. Применялся модирицированный вариант методики «Оценочно-содержательная интерпретация внешнего облика и его соответствия гендерно-возрастным конструктам» (В.A. Лабунская, 2009), где в качестве объектов оценки выступают типы внешнего облика: "Славянский внешний облик», “Кавказский внешний облик» и "Азиатский внешний облик», их гендерная принадлежность. Показано, что существуют статистически значимые различия в степени позитивности различных видов оценок внешнего облика в зависимости от его этнокультурного типа. Гендерная принадлежность объекта оценки также оказывает влияние на степень позитивности оценок определенных типов внешнего облика.

Ключевые слова: гендер, этнокультурный внешний облик, Славянский внешний облик, Кавказский внешний облик, Азиатский внешний облик, степень позитивности оценок, дискриминационное отношение, дискриминация, этнокультурная группа, интегральная оценка.
\end{abstract}

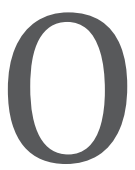

том, что внешность всегда включена в гендерно-возрастные стереотипы, является репрезентацией феминности/маскулинности, статусно-ролевых характеристик личности, ее системы отношений с миром, пишет В.А. Лабунская ${ }^{1}$, отмечая, что внешний облик, являясь, «бесконечно интерпретируемым объектом познания»², становится одним из средств построения типологий, выделения и распознания определенных социальных групп (В.А. Лабунская ${ }^{3}$ ). Внешний облик человека, в частности, является презентацией при-

\footnotetext{
1 Лабунская В.А. Самооценка внешнего облика на различных этапах жизненного пути // Развитие психологии в системе комплексного человекознания / под ред. А.Л. Журавлева, В.А. Кольцовой. Ч. 1. М.: Институт психологии РАН, 2012. C. 331-338.

2 Лабунская В.А. «Видимый человек» как социально-психологический феномен // Социальная психология и общество. 2010. № 1. С. 27.

3 Там же. С. 26-39.
}

надлежности человека к определенной этнической группе, демонстрацией этнической идентичности.

Этнокультурный внешний облик также может играть роль в том, как люди воспринимают себя, а типичность своего внешнего облика для этнической группы, как утверждают M.A. Gonzales-Backen, A.J. Uma na-Taylor4 может быть положительно связана с самооценкой и самоотношением. Так, внешний облик может усиливать идентификацию со своей этнической группой, когда, к примеру, люди, имеющие типичную для латиноамериканцев темную кожу и Latino-внешний облик, формируют положительную этническую идентичность и чувствуют себя особенно связанными со своей этнической группой. Однако, тогда возникает вопрос об «обратном влиянии»:

\footnotetext{
4 Gonzales-Backen M.A., Uma na-Taylor A.J. Examining the role of physical appearance in Latino adolescentsethnic identity // Journal of Adolescence. 2011. № 34. P. 151-162 (URL: http:// www.sciencedirect.com/science/article/pii/S014019711000014X (Дата посещения: 10.09.2013)).
} 
может ли «атипичность» внешнего облика «другого» человека для «своей» этнической группы оказывать влияние на отношение к нему?

В западных работах, посвященных проблемам, касающихся дискриминации человека по тем или иным признакам, особое внимание исследователей привлекает относительно новое понятие «лукизм» (англ. Lookism), которое представляет собой дискриминационное отношение к человеку, основанное на его внешнем облике или «предпочтительное обращение с привлекательными людьми и отказ в возможностях для непривлекательных людей» ${ }^{5}$. Так, Louis Tietje, Steven Cresap ${ }^{6}$ приводят, примеры лукизма в сфере труда, когда непривлекательные люди получают штрафы, привлекательность/непривлекательность связывается с эффективностью труда, а наем привлекательного персонала, оказывается успешной стратегией для некоторых компаний. Однако, дискриминация на основе внешнего облика не ограничивается сферой труда и проникает в повседневное взаимодействие, когда, к примеру мужчины с большей готовностью помогают привлекательным женщинам, чем не привлекательным ${ }^{7}$.

Исходя из определения лукизма, можно сказать, что дискриминация по внешнему облику включает в себя категоризацию людей, в основе которой лежит оценка внешнего облика. Позитивность/негативность совокупности оценок различных типов внешнего облика является одним из показателей дискриминационного отношения, включенного в когнитивную составляющую дискриминации. Исходя из этого вывода, на основе совокупности оценок типов внешнего облика можно судить о выраженности дискриминационного отношения к представителям этнокультурных групп, отличающихся гендерной принадлежностью.

Роль внешнего облика как пускового механизма этнической дискриминации в отечественной психологии практически не изучена, несмотря на актуальность данной проблемы, о которой свидетельствуют, например, практики «этнический профайлинг» или «этнический face control», много-

\footnotetext{
5 Суэми В., Фернхем А. Психология красоты и привлекательности. СПб.: Питер, 2009. С. 187.

6 Louis Tietje and Steven Cresap. Is lookism unjust?: the ethics of aesthetics and public policy implications // Journal of libertarian studies. Volume 19, № 2 (spring 2005). P. 31-50.

Суэми В., Фернхем А. Психология красоты и привлекательности. СПб.: Питер, 2009. С. 187.
}

численные примеры которых транслируются СМИ. Так, представители определенного этнокультурного внешнего облика могут быть не допущены в заведения в силу субъективных критериев оценки внешности и черт лица: в якутский ночной клуб не пустили армянина, пришедшего в компании, так как, по распоряжению руководства, «лицам кавказской национальности» вход запрещен ${ }^{8}$. Нередки и случаи «этнического профайлинга» когда полиция, проверяя документы людей, принадлежащих по внешним признакам к определенной национальности, предполагают, что именно этническая принадлежность автоматически повышает вероятность того, что человек является преступником $^{9}$. К примеру, результаты исследования «этнической избирательности милиции», проведенного в 2005 году в московском метро, показали, что вероятность быть остановленными милицией у лиц с «неславянской» внешностью в 21,8 раза выше, чем у лиц славянского типа внешнего облика ${ }^{10}$. Ряд зарубежных авторов отмечает, что в контексте американской культуры, ключевым признаком внешнего облика при дискриминации представителей определенной этнорасовой принадлежности выступает цвет кожи (J. Hersch ${ }^{11}$, S. Abdulrahim, S.A. James, R. Yamout, W. Baker ${ }^{12}$ ). В отечественной науке изучается влияние расового типа воспринимаемого лица на адекватность суждений о личности его обладателя (К.И. Ананьева ${ }^{13}$ ), лицо как объект антропоэстетического выбора (Н.И. Халдеева ${ }^{14}$ ), однако влияние этнокультурного типа внешнего об-

\footnotetext{
8 Иванова A. Клуб «Love»: только для белых? // Наше Время. 2010. № 4. (URL: http://www.sova-center.ru/racism-xenophobia/ news/racism-nationalism/2010/01/d17879/).

9 Кириченко К.А., Сабунаева М.Л. Дискриминация ЛГБТ: что, как и почему? СПб.: Выход, 2012. 104 с.

10 URL: http://www.etnosite.ru/news/1/11451.html.

11 Hersch J. Skin color, physical appearance, and perceived discriminatory treatment // The Journal of Socio-Economics. Volume 40. Issue 5. October 2011. P. 671-678.

12 Abdulrahim S., James S.A., Yamout R., Baker W. Discrimination and psychological distress: Does Whiteness matter for Arab Americans? // Social Science \& Medicine. Volume 75. Issue 12. December 2012. P. 2116-2123.

13 Ананьева К.И. Идентификация и оценка лиц людей разной расовой принадлежности. Автореф. дисс. ... к. психол. н. М., 2009. 24 c.

14 Лицо человека как средство общения: междисциплинарный подход / Отв. ред. В.А. Барабанщиков, А.А. Демидов,
} Д.А. Дивеев. М.: Когнито центр. 2012. 348 с. 


\section{Профессиональная психология}

лика в контексте дискриминационного отношения остается недостаточно изученным.

В рамках другого направления исследований, где в качестве предиктора дискриминации рассматривается гендер объекта, изучается гендерная дискриминация или дискриминации по признаку пола (Е.А. Житникова ${ }^{15}$, Э.И. Фазлиахметова ${ }^{16}$ ). Когда говорят о дискриминации по признаку пола или гендерной дискриминации, чаще всего имеют ввиду дискриминацию женщин, возможно потому что, как подчеркивает И.С. Клецина, женщины чаще, чем мужчины сталкиваются с явлениями дискриминации и насилия (И.С. Клецина ${ }^{17}$ ), хотя в последнее время начинают говорить о дискриминации мужчин (David Benatar ${ }^{18}$ ), которые все чаще становятся объектами дискриминации и выступают за сохранение своих прав, организовывая общественные движения против мужской дискриминации. Сегодня, как пишет D. Benatar, меньше мальчиков оканчивают школы, меньше мужчин получают дипломы о высшем образовании и научные степени, среди мужчин выше численность заключенных и пр. В некоторых работах проблема гендерной дискриминации рассматривается в связи с дискриминацией на основе внешнего облика, к примеру, в сфере труда (Stan Malos ${ }^{19}$ ), однако данные исследования носят фрагментарный характер. В целом, влияние гендера типа внешнего облика на степень позитивности оценок внешнего облика (являющейся одним из показателей дискриминационного отношения) остается неизученным.

В предыдущих исследованиях было показано, что большинство участников исследования склонны проявлять дискриминационное отношение к

15 Житникова Е.А. Гендерная дискриминация и особенности ее проявления в России // Вестник Чувашского университета. 2010. № 2. С. 364-368.

16 Фазлиахметова Э.И. Самоактуализация личности в профессиях с преимущественно мужской и женской занятостью. Автореф. дисс. .... к. психол. н. Тамбов, 2010. 24 с.

17 Клецина И.С. Психология гендерных отношений. Автореф. дисс. ... д. психол. н. СПб, 2004. С. 39.

18 Benatar David. The second sexism: discrimination against man and boys. John Wiley \& Sons, 2012. 304 p. (URL: http://www. amazon.com/The-Second-Sexism-Discrimination-Against/dp/0 470674512\#reader_0470674512).

19 Stan Malos. Appearance-based Sex Discrimination and Stereotyping in the Workplace: Whose Conduct Should We Regulate? // Springer Science + Business Media, LLC 2007. P. 1-17. (URL: http://www.cob.sjsu.edu/malos_s/Malos\%20ERRJ-Appearance\%20Discrimination.pdf). человеку, ориентируясь на этнокультурный тип его внешнего облика (А.А. Бзезян ${ }^{20}$ ). В данном исследовании осуществляется проверка следующей гипотезы: степень позитивности различных видов оценок типов внешнего облика может быть обусловлена его этнокультурной и гендерной принадлежностью. С целью проверки выдвинутой гипотезы был осуществлен сравнительный анализ позитивности / негативности оценок мужского и женского внешнего облика различных этнокультурных типов.

Эмпирический объект исследования: 50 молодых людей, 37 девушек и 15 юношей в возрасте от 19 до 25 лет, большинство из которых принадлежат к этнической группе «русские» (70\%).

\section{Методика исследования:}

Методика «Оценка степени привлекательности различных типов внешнего облика» представляет собой модификацию методики В.А. Лабунской ${ }^{21}$ «Оценочно-содержательная интерпретация своего внешнего облика и его соответствия гендерно-возрастным конструктам». Отличие применяемого в исследовании опросника от базовой методики заключается в том, что в нем в качестве объектов оценки выступают типы внешнего облика: «Славянский внешний облик», «Кавказский внешний облик», «Азиатский внешний облик», визуальные презентации которых адекватно соотносятся большинством участников исследования (А.А. Бзезян ${ }^{22}$ ). Названия перечисленных типов внешнего облика соответствует принятым антропологическим классификациям (Я.Я. Рогинский, М.Г. Левин ${ }^{23}$ ). В методике

20 Бзезян А.А. Проявление дискриминационного отношения в различных ситуациях взаимодействия в связи с оценкой внешнего облика тех или иных этнических групп // Актуальные проблемы психологической теории и практики: материалы международной научно-практической конференции студентов, аспирантов и молодых ученых (г. Донецк, 5 апреля 2013 г.) / За заг. Ред. Кафедри психологіi ДонНУ. Донецьк: ТОВ «Східний видавничий дім», 2013. С. 29-33.

21 Лабунская В.А. Не язык тела, а язык души! Психология невербального выражения личности. Ростов н/Д: Феникс, 2009. $344 \mathrm{c}$

22 Бзезян А.А. Особенности идентификации визуальных репрезентаций внешнего облика с расовой и этнической принадлежностью человека // Материалы антитеррористического фестиваля студенческой, научной и творческой молодёжи «Мир Кавказу». Ростов-на-Дону, 12-14 ноября 2012 г. Том 1. М.: КРЕДО, 2013. С. 43-52.

23 Антропология: учебное пособие / ред. Я.Я. Рогинский, М.Г. Левин. М.: Высшая школа, 1978. 528 с. 


\section{Психология и психотехника 1(64) • 2014}

Оценки женского этнокультурного типа внешнего облика

\begin{tabular}{|c|c|c|c|}
\hline Вид оценки & $\begin{array}{c}\text { Этнокультурные } \\
\text { типы внешнего облика }\end{array}$ & Z -критерий & $\begin{array}{c}\text { Уровень } \\
\text { значимости }\end{array}$ \\
\hline \multirow{3}{*}{ Эстетическая оценка лица } & $\mathrm{KBO}<\mathrm{CBO}$ & $-4,251$ &, 000 \\
\hline & $\mathrm{ABO}<\mathrm{CBO}$ & $-5,758$ &, 000 \\
\hline & $\mathrm{KBO}>\mathrm{ABO}$ & $-3,826$ &, 000 \\
\hline \multirow{2}{*}{ Эстетическая оценка телосложения } & $\mathrm{CBO}>\mathrm{KBO}$ & $-3,838$ & .000 \\
\hline & $\mathrm{ABO}<\mathrm{CBO}$ & $-5,156$ &, 000 \\
\hline \multirow{2}{*}{ Эстетическая оценка оформления внешнего облика } & $\mathrm{CBO}>\mathrm{KBO}$ & $-4,628$ &, 000 \\
\hline & $\mathrm{ABO}<\mathrm{CBO}$ & $-5,045$ &, 000 \\
\hline \multirow{2}{*}{ Привлекательность внешнего облика для противоположного пола } & $\mathrm{CBO}>\mathrm{KBO}$ & $-5,128$ &, 000 \\
\hline & $\mathrm{ABO}<\mathrm{CBO}$ & $-5,780$ &, 000 \\
\hline \multirow{3}{*}{ Степень соответствия внешнего облика гендеру } & $\mathrm{CBO}>\mathrm{KBO}$ & $-4,720$ &, 000 \\
\hline & $A B O<K B O$ & $-2,012$ & 044 \\
\hline & $\mathrm{CBO}>\mathrm{ABO}$ & $-5,347$ &, 000 \\
\hline
\end{tabular}

Пояснения к таблицам № 1, № 2: СВО - Славянский внешний облик, КВО - Кавказский внешний облик, $A B O-$ - Азиатский внешний облик.

используется 10-балльная система, где 1 - крайне негативная оценка, 2-4 - отрицательные оценки, 5-6 - средне-позитивные оценки, 7-9 - позитивные оценки, 10 - самая высокая позитивная оценка. В первой и второй частях (21 утверждение в каждой части) методики респондентам предлагается оценить по степени привлекательности определенный женский и мужской тип внешнего облика («Славянский внешний облик», «Кавказский внешний облик», «Азиатский внешний облик»). Данные части методики включают в себя по три блока: 1-3 блоки утверждений состоят из тех характеристик внешнего облика, которые были названы Лабунской В.А. «Эстетическая оценка внешнего облика» (красивый-некрасивый, выразительный-невыразительный, притягательный-непритягательный, обаятельный-необаятельный). Также блоки 1-3 включают в себя оценку привлекательности для противоположного пола, оценку соответствия определенного внешнего облика гендеру и оценку соответствия определенного внешнего облика этнической группе респондента. На основе методики определяются: 1. Оценка лица представителя определенного типа внешнего облика - блок 1. 2. Оценка телосложения определенного типа внешнего облика - блок 2. 3. Оценка оформления определенного типа внешнего облика - блок 3. «Эстетические оценки» лица, телосложения и оформления внешнего облика в совокупности представляют собой интегральную эстетическую оценку внешнего облика представителя определенной этнокультурной группы. Оценки привлекательности для противоположного пола таких компонентов внеш- него облика как лица, телосложения и оформления суммировались в интегральную оценку привлекательности для противоположного пола внешнего облика. Оценки степени соответствия лица, телосложения и оформления внешнего облика гендеру суммировались аналогичным образом, представляя собой интегральную оценку соответствия внешнего облика гендеру.

Для определения различий в степени позитивности/негативности оценок женского и мужского «Славянского внешнего облика», «Кавказского внешнего облика» и «Азиатского внешнего облика» применялся непараметрический Z-критерий Вилкоксона (программа SPSS 16.00).

\section{Результаты исследования:}

После проведения сравнительного анализа степени позитивности оценок мужского и женского внешнего облика различных этнокультурных типов было выявлено, что существуют значимые различия на деципроцентном уровне $(\mathrm{p}<0,001)$ в степени позитивности оценок женского внешнего облика различных этнокультурных типов (Таблица № 1).

Респонденты значимо ниже оценивают женский азиатский и кавказский внешний облик, чем женский славянский внешний облик по эстетическим оценкам лица ( $\mathrm{z}=-5,758 ; \mathrm{z}=-4,251)$, причем эстетические оценки лица женщин кавказского внешнего облика значимо выше, по сравнению с оценками лица женщин азиатского внешнего облика $(\mathrm{z}=-3,826)$. По эстетическим оценкам телосложения женский славянский тип внешнего 
Профессиональная психология

Оценки мужского этнокультурного типа внешнего облика

таблица 2

\begin{tabular}{|c|c|c|c|}
\hline Вид оценки & $\begin{array}{c}\text { Этнокультурные типы } \\
\text { внешнего облика }\end{array}$ & Z -критерий & $\begin{array}{c}\text { Уровень } \\
\text { значимости }\end{array}$ \\
\hline \multirow{3}{*}{ Эстетическая оценка лица } & $\mathrm{KBO}<\mathrm{CBO}$ & $-3,748$ &, 000 \\
\hline & $\mathrm{ABO}<\mathrm{CBO}$ & $-5,713$ &, 000 \\
\hline & $\mathrm{ABO}<\mathrm{KBO}$ & $-2,593$ & 010 \\
\hline \multirow{3}{*}{ Эстетическая оценка телосложения } & $\mathrm{CBO}>\mathrm{KBO}$ & $-3,431$ & ,001 \\
\hline & $\mathrm{ABO}>\mathrm{KBO}$ & $-2,786$ & ,005 \\
\hline & $\mathrm{ABO}<\mathrm{CBO}$ & $-5,356$ &, 000 \\
\hline \multirow{2}{*}{ Эстетическая оценка оформления внешнего облика } & $\mathrm{KBO}<\mathrm{CBO}$ & $-5,076$ &, 000 \\
\hline & $\mathrm{ABO}<\mathrm{CBO}$ & $-5,226$ & .000 \\
\hline \multirow{3}{*}{ Привлекательность внешнего облика для противоположного пола } & $\mathrm{KBO}<\mathrm{CBO}$ & $-4,410$ &, 000 \\
\hline & $\mathrm{ABO}<\mathrm{CBO}$ & $-5,938$ &, 000 \\
\hline & $\mathrm{ABO}<\mathrm{KBO}$ & $-2,675$ &, 007 \\
\hline \multirow{3}{*}{ Степень соответствия внешнего облика гендеру } & $\mathrm{CBO}>\mathrm{KBO}$ & $-2,175$ &, 030 \\
\hline & $\mathrm{ABO}<\mathrm{KBO}$ & $-4,694$ &, 000 \\
\hline & $\mathrm{ABO}<\mathrm{CBO}$ & $-5,678$ &, 000 \\
\hline
\end{tabular}

облика оценивался значимо выше, чем женский кавказский тип внешнего облика $(\mathrm{z}=-3,838)$. Эстетические оценки телосложения женского азиатского внешнего облика были значимо ниже оценок женского славянского типа внешнего облика $(\mathrm{z}=-5,156)$. Можно наблюдать следующую тенденцию: телосложение женского азиатского внешнего облика оценивалось ниже, чем женщин кавказского внешнего облика $(\mathrm{z}=-1,930$ при $\mathrm{p}=0,054)$. Существуют значимые различия ( при $р<0,001)$ в эстетических оценках оформления внешнего облика: оценки женского славянского внешнего облика значимо выше оценок женского кавказского внешнего облика $(\mathrm{z}=-4,628)$. Оценки оформления внешнего облика женщин азиатского типа были значимо ниже оценок оформления внешнего облика женщин славянского типа (z=-5,045). По шкале «Привлекательность для противоположного пола» так же были обнаружены значимые различия между оценками женского внешнего облика различных этнокультурных типов: оценки женского славянского внешнего облика значимо выше оценок женского кавказского внешнего облика $(\mathrm{z}=-5,128)$. Женский азиатский внешний облик оценивался респондентами по данной шкале значимо ниже женского славянского типа внешнего облика $(\mathrm{z}=-$ $5,780)$ и на уровне тенденции ниже женского кавказского внешнего облика $(\mathrm{z}=-2,144$ при $\mathrm{p}=0,032)$. По «Степени соответствия внешнего облика гендеру» женский славянский тип внешнего облика оценивался значимо выше женского кавказского и азиатского внешнего облика $(\mathrm{z}=-4,720 ; \mathrm{z}=-6,126$, при $\mathrm{p}<0,001)$, при этом женский азиатский внеш- ний облик оценивался ниже женского кавказского внешнего облика (z=-2,012, при $\mathrm{p}=0,044)$.

Существуют значимые различия на высоком уровне $(\mathrm{p}<0,001)$ в степени позитивности оценок мужского внешнего облика различных этнокультурных типов (Таблища №2).

Респонденты значимо ниже оценивают мужской кавказский и азиатский внешний облик по эстетическим оценкам лица, по сравнению с оценками мужского славянского внешнего облика $(\mathrm{z}=3,748 ; \mathrm{z}=5,713)$. При этом мужской азиатский внешний облик оценивается значимо ниже мужского кавказского внешнего облика по данной шкале $(\mathrm{z}=-2,593$, при $\mathrm{p}=0,01)$. По эстетическим оценкам телосложения мужской славянский внешний облик оценивается значимо выше мужского кавказского внешнего облика $(\mathrm{z}=-3,431$, при $\mathrm{p}<0,01)$. Эстетические оценки телосложения мужского азиатского типа внешнего облика значимо ниже оценок мужского славянского типа внешнего облика $(\mathrm{z}=-5,356$ при $\mathrm{p}<0,001)$ и ниже оценок телосложения мужского кавказского внешнего облика $(\mathrm{z}=-2,786$ при $\mathrm{p}<0,01)$. Существуют значимые различия ( при $\mathrm{p}<0,001)$ в эстетических оценках оформления внешнего облика, где мужской кавказский и азиатский внешний облик оценивались значимо ниже мужского славянского внешнего облика $(\mathrm{z}=-5,076, \mathrm{z}=-5,226)$. По шкале «Привлекательность для противоположного пола» так же были обнаружены значимые различия между оценками мужского внешнего облика различных этнокультурных типов: мужской азиатский и кавказский внешний облик оценивались значимо ниже муж- 


\section{Психология и психотехника 1(64) • 2014}

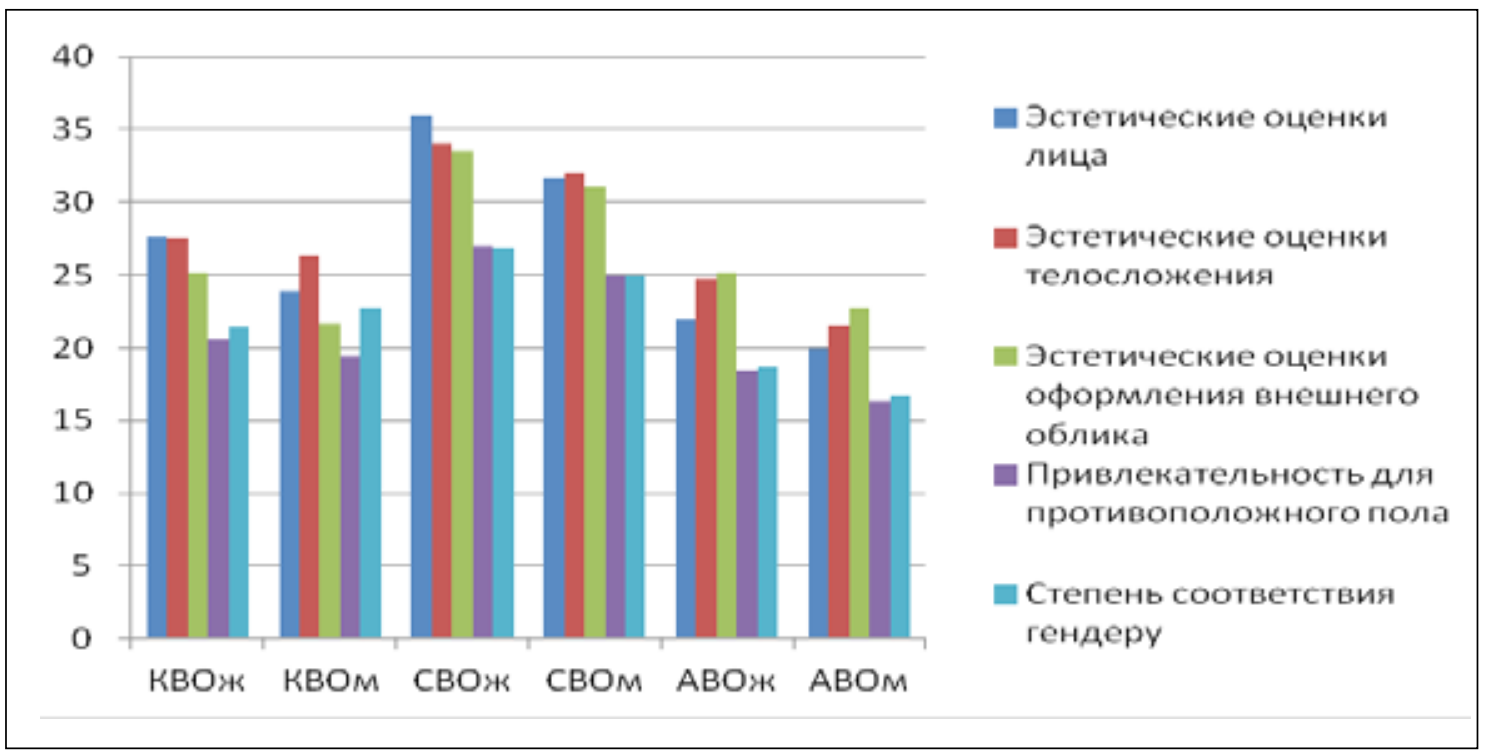

Пояснения к графику № 1: СВО ж - женский славянский внешний облик, КВО ж - женский кавказский внешний облик, АВО ж - женский азиатский внешний облик, СВО м - мужской славянский внешний облик, КВО м - мужской кавказский внешний облик, $A B O$ м - мужской азиатский внешний облик.

ского славянского внешнего облика $(\mathrm{z}=-5,938 ; \mathrm{z}=-$ $4,410)$. Привлекательность для противоположного пола мужского азиатского типа внешнего облика оценивалась значимо ниже мужского кавказского типа внешнего облика $(\mathrm{z}=-2,675$, при $\mathrm{p}<0,01)$. По степени соответствия внешнего облика гендеру на уровне тенденции мужской славянский тип внешнего облика оценивался выше мужского кавказского внешнего облика (z=-2,175, при $\mathrm{p}=0,030)$. Мужской азиатский тип внешнего облика по данной шкале оценивался значимо ниже мужского славянского и кавказского типов внешнего облика $(\mathrm{z}=-5,678 ; \mathrm{z}=-4,694$ при $\mathrm{p}<0,001)$.

Влияние гендерной принадлежности объекта оценки на степень позитивности оценок типов внешнего облика проявилось в том, что вне зависимости от этнокультурной принадлежности, средние значения по всем видам оценок мужского внешнего облика различных этнокультурных групп были ниже оценок женского внешнего облика различных типов (График № 1).

Сравнительный анализ показал, что существуют значимые различия $(\mathrm{p}<0,01)$ в степени позитивности/негативности интегральной эстетической оценки внешнего облика, в зависимости от гендера объекта оценки: интегральная эстетическая оценка мужского внешнего облика («Славянского внешнего облика», «Кавказского внешнего облика» и «Азиат- ского внешнего облика») оценивается респондентами значимо ниже интегральной эстетической оценки женского внешнего облика ( $\mathrm{Z}=-3,924,-3,067,-2,953)$.

\section{Заключение}

Таким образом, по результатам исследования, можно говорить о том, что гипотеза нашла свое подтверждение: степень позитивности различных видов оценки типов внешнего облика может быть обусловлена его этнокультурной и гендерной принадлежностью.

Существуют статистически значимые различия в степени позитивности/негативности оценок внешнего облика представителей различных этнокультурных типов. В целом, степень позитивности мужского и женского славянского внешнего облика значимо выше внешнего облика кавказского и азиатского типа. Мужской и женский славянский облик получает самую высокую интегральную эстетическую оценку внешнего облика. Самые негативные оценки получают мужской и женский азиатский внешний облик. Так же были обнаружены значимые различия в степени позитивности между «Оценками привлекательности типов внешнего облика для противоположного пола», где самые негативные оценки привлекательности внешнего облика для противоположного пола получает женский и мужской тип 


\section{Профессиональная психология}

азиатского внешнего облика. Было выявлено, что «Степень соответствия внешнего облика гендеру» также оценивалась в зависимости от типа внешнего облика: женский славянский тип внешнего облика оценивается как более женственный, чем женский кавказский и азиатский типы внешнего облика, мужской славянский тип внешнего облика оценивается как более мужественный, чем мужской кавказский и азиатский типы внешнего облика, при этом мужской кавказский тип внешнего облика получает более высокие оценки степени соответствия гендеру, по сравнению с мужским азиатским типом внешнего облика.

Влияние гендерной принадлежности объекта оценки на степень позитивности оценок типов внешнего облика проявилось в том, что вне зависимости от этнокультурной принадлежности, женский внешний облик получает более позитивные оценки, относительно мужского внешнего облика, интегральная эстетическая оценка которого оценивалась значимо ниже.

Данные выводы позволяют говорить о том, что степень позитивности/негативности оценок внешнего облика обусловлена не только его этнокультурной, но и гендерной принадлежностью объекта оценки. Дискриминационное отношение, проявляющееся в степени негативности оценок типов внешнего облика, более выражено в отношении мужского внешнего облика.

\section{Список литературы:}

1. Ананьева К.И. Идентификация и оценка лиц людей разной расовой принадлежности. Автореф. дисс... к. психол. н. М., 2009. 24 с.

2. Антропология: учебное пособие / ред. Я.Я. Рогинский, М.Г. Левин. М.: Высшая школа, 1978. 528 с.

3. Бзезян А.А. Особенности идентификации визуальных репрезентаций внешнего облика с расовой и этнической принадлежностью человека // Материалы антитеррористического фестиваля студенческой, научной и творческой молодёжи «Мир Кавказу». Ростов-на-Дону, 12-14 ноября 2012 г. Том 1. М.: КРЕДО, 2013. С. 43-52.

4. Бзезян А.А. Проявление дискриминационного отношения в различных ситуациях взаимодействия в связи с оценкой внешнего облика тех или иных этнических групп // Актуальные проблемы психологической теории и практики: материалы международной научно-практической конференции студентов, аспирантов и молодых ученых (г. Донецк, 5 апреля 2013 г.) / За заг. ред. Кафедри психологіі ДонНУ. Донецьк: ТОВ «Східний видавничий дім», 2013. С. 29-33.

5. Житникова Е.А. Гендерная дискриминация и особенности ее проявления в России // Вестник Чувашского университета. 2010. № 2. С. 364-368.

6. Кириченко К.А., Сабунаева М.Л. Дискриминация ЛГБТ: что, как и почему? СПб.: Выход, 2012.104 с.

7. Клецина И.С. Психология гендерных отношений. Автореф. дисс... д. психол. н. СПб, 2004.

8. Кулагина Н.В. Внутриличностный гендерный конфликт профессиональной роли у работающих мужчин и женщин: состояние проблемы и некоторые пути её решения // NB: Психология и психотехника. 2013. № 2. C. 138-228. (URL: http://www.e-notabene.ru/psp/article_276.html).

9. Лабунская В.А. «Видимый человек» как социально-психологический феномен // Социальная психология и общество. 2010. № 1. С. 26-39.

10. Лабунская В.А. Не язык тела, а язык души! Психология невербального выражения личности. Ростов н/Д: Феникс, 2009. 344 с.

11. Лабунская В.А. Самооценка внешнего облика на различных этапах жизненного пути // Развитие психологии в системе комплексного человекознания / под ред. А.Л. Журавлева, В.А. Кольцовой. Ч. 1. М.: Институт психологии РАН, 2012. С. 331-338.

12. Лицо человека как средство общения: междисциплинарный подход / Отв. ред. В.А. Барабанщиков, А.А. Демидов, Д.А. Дивеев. М.: Когнито центр, 2012. 348 с.

13. Суэми В., Фернхем А. Психология красоты и привлекательности. СПб.: Питер, 2009.

14. Толстокорова А.В. Социальные проблемы трудовой миграции в Украине: возрастное и гендерное измерения // NB: Проблемы общества и политики. 2012. № 2. C. 64-87. (URL: http://www.e-notabene.ru/ pr/article_233.html).

15. Фазлиахметова Э.И. Самоактуализация личности в профессиях с преимущественномужской и женской занятостью. Автореф. дисс... к. психол. н. Тамбов, 2010. 24 с. 


\section{Психология и психотехника 1(64) • 2014}

16. Abdulrahim S., James S. A., Yamout R., Baker W. Discrimination and psychological distress: Does Whiteness matter for Arab Americans? // Social Science \& Medicine. Volume 75. Issue 12. December 2012. P. 21162123.

17. Benatar David. The second sexism: discrimination against man and boys. John Wiley \& Sons, 2012. 304 p. (URL: http://www.amazon.com/The-Second-Sexism-Discrimination-Against/dp/0470674512\#read er_0470674512).

18. Gonzales-Backen M.A.,Uma na-Taylor A.J.Examining theroleofphysicalappearancein Latinoadolescents'ethnic identity // Journal of Adolescence. 2011. № 34. P. 151-162. (URL: http://www.sciencedirect.com/science/ article/pii/S014019711000014X).

19. Hersch J. Skin color, physical appearance, and perceived discriminatory treatment // The Journal of SocioEconomics. Volume 40. Issue 5. October 2011. P. 671-678.

20. Stan Malos. Appearance-based Sex Discrimination and Stereotyping in the Workplace: Whose Conduct Should We Regulate? // Springer Science + Business Media, LLC 2007. P. 1-17. (URL: http://www.cob.sjsu. edu/malos_s/Malos\%20ERRJ--Appearance\%20Discrimination.pdf).

\section{References (transliteration):}

1. Anan'eva K.I. Identifikatsiya i otsenka lits lyudei raznoi rasovoi prinadlezhnosti. Avtoref. diss... k. psikhol. n. M., 2009. $24 \mathrm{~s}$.

2. Antropologiya: uchebnoe posobie / red. Ya.Ya. Roginskii, M.G. Levin. M.: Vysshaya shkola, 1978. 528 c.

3. Bzezyan A.A. Osobennosti identifikatsii vizual'nykh reprezentatsii vneshnego oblika s rasovoi i etnicheskoi prinadlezhnost'yu cheloveka // Materialy antiterroristicheskogo festivalya studencheskoi, nauchnoi i tvorcheskoi molodezhi «Mir Kavkazu». Rostov-na-Donu, 12-14 noyabrya 2012 g. Tom 1. M.: KREDO, 2013. S. 43-52.

4. Bzezyan A.A. Proyavlenie diskriminatsionnogo otnosheniya $\mathrm{v}$ razlichnykh situatsiyakh vzaimodeistviya $\mathrm{v}$ svyazi s otsenkoi vneshnego oblika tekh ili inykh etnicheskikh grupp // Aktual'nye problemy psikhologicheskoi teorii i praktiki: materialy mezhdunarodnoi nauchno-prakticheskoi konferentsii studentov, aspirantov i molodykh uchenykh (g. Donetsk, 5 aprelya 2013 g.) / Za zag. red. Kafedri psikhologii DonNU. Donets'k: TOV «Skhidnii vidavnichii dim», 2013. S. 29-33.

5. Zhitnikova E.A. Gendernaya diskriminatsiya i osobennosti ee proyavleniya v Rossii // Vestnik Chuvashskogo universiteta. 2010. № 2. S. 364-368.

6. Kirichenko K.A., Sabunaeva M.L. Diskriminatsiya LGBT: chto, kak i pochemu? SPb.: Vykhod. 2012.104 s.

7. Kletsina I.S. Psikhologiya gendernykh otnoshenii. Avtoref. diss... d. psikhol. n. SPb, 2004.

8. Kulagina N.V. Vnutrilichnostnyi gendernyi konflikt professional'noi roli u rabotayushchikh muzhchin i zhenshchin: sostoyanie problemy i nekotorye puti ee resheniya // NB: Psikhologiya i psikhotekhnika. 2013. № 2. S. 138-228. (URL: http://www.e-notabene.ru/psp/article_276.html).

9. Labunskaya V.A. «Vidimyi chelovek» kak sotsial'no-psikhologicheskii fenomen // Sotsial'naya psikhologiya i obshchestvo. 2010. № 1. S. 26-39.

10. Labunskaya V.A. Ne yazyk tela, a yazyk dushi! Psikhologiya neverbal'nogo vyrazheniya lichnosti. Rostov n/D: Feniks, 2009. $344 \mathrm{~s}$.

11. Labunskaya V.A. Samootsenka vneshnego oblika na razlichnykh etapakh zhiznennogo puti // Razvitie psikhologii v sisteme kompleksnogo chelovekoznaniya / pod red. A.L. Zhuravleva, V.A. Kol'tsovoi. Ch. 1. M.: Institut psikhologii RAN, 2012. S. 331-338.

12. Litso cheloveka kak sredstvo obshcheniya: mezhdistsiplinarnyi podkhod / Otv. red. V.A. Barabanshchikov, A.A. Demidov, D.A. Diveev. M.: Kognito tsentr, 2012. 348 s.

13. Suemi V., Fernkhem A. Psikhologiya krasoty i privlekatel'nosti. SPb.: Piter, 2009.

14. Tolstokorova A.V. Sotsial'nye problemy trudovoi migratsii v Ukraine: vozrastnoe i gendernoe izmereniya // NB: Problemy obshchestva i politiki. 2012. № 2. S. 64-87. (URL: http://www.e-notabene.ru/pr/article_233.html).

15. Fazliakhmetova E.I. Samoaktualizatsiya lichnosti v professiyakh s preimushchestvennomuzhskoi i zhenskoi zanyatost'yu. Avtoref. diss... k. psikhol. n. Tambov, 2010. 24 s. 